\title{
SPESIFIEKE TAALGESTREMDHEID EN TAALWETENSKAPLIKE TEORIE: 'N EVALUERENDE OORSIG
}

\author{
Frenette Southwood, Universiteit Stellenbosch
}

\section{INLEIDING}

Alhoewel spesifieke taalgestremdheid (STG) nie 'n nuwe studieveld is nie', is die ontwikkeling van teoretiese verklarings vir STG wel 'n relatief onlangse fokus binne hierdie veld. Tans is daar twee hooftipes verklarings vir STG, naamlik sogenaamde "linguistiese" verklarings en prosesseringsverklarings. Hierdie artikel gee 'n inleidende oorsig oor prominente verklarings wat in hierdie twee kategorieë val ${ }^{2}$. Daar is verskeie ander verklarings vir $\mathrm{STG}^{3}$ wat nie hier bespreek sal word nie, aangesien die artikel 'n beperkte doel het, naamlik om aan te toon hoe taalwetenskaplike teorie ingespan kan word vir die wetenskaplike verduideliking van die verskynsel van STG, eerder as om 'n gedetailleerde uiteensetting van alle verklarings vir STG te gee.

Die artikel word ingelei met 'n algemene bespreking van die eienskappe van STG in afdeling 2. Vyf linguistiese verklarings vir STG, wat elk tot 'n mindere of meerdere mate hierdie eienskappe kan verklaar, word in afdeling 3 bespreek, terwyl twee prosesseringsverklarings in afdeling 4 bespreek word. Die verklarings in afdelings 3 en 4 is grootliks op grond van Engelse data opgestel. In afdeling 5 word daar kortliks gekyk na die waarde van Afrikaans om die verklarende meriete van hierdie verklarings te evalueer. 'n Slotperspektief, wat fokus op die belang van die voortgesette studie van STG, word in afdeling 6 gegee.

\section{EIENSKAPPE VAN SPESIFIEKE TAALGESTREMDHEID}

Die meeste data oor die eienskappe van die taal van kinders met STG (voortaan "STGkinders") is van Engelssprekende kinders versamel. Wat kortliks in hierdie afdeling bespreek word, is gevolglik grootliks hoe STG in Engels presenteer, in terme van die leksikon (afdeling 2.1), sintaksis (afdeling 2.2), fonologie (afdeling 2.3), en pragmatiek (afdeling 2.4) van STGkinders. 


\section{$2.1 \quad$ Leksikon}

In terme van vroeë leksikale ontwikkeling is die algemene tendens dat STG-kinders hul eerste woorde later produseer as tipies-ontwikkelende kinders (Leonard 1998:43). In terme van kwaliteit gebruik STG-kinders dieselfde tipe woorde as hul tipies-ontwikkelende eweknieë. Watkins, Rice, en Molz (1993) het egter bevind dat STG-kinders op preprimêre skool ouderdom 'n meer beperkte verskeidenheid werkwoorde (en klaarblyklik geld dit net vir werkwoorde) gebruik as wat tipies-ontwikkelende kinders van dieselfde ouderdom (voortaan "ouderdomkontroles") asook jonger kinders met dieselfde gemiddelde lengte van uiting as dié van die STG-kinders (voortaan "GLU-kontroles") van preprimêre skool ouderdom gebruik.

In terme van die aanleer van leksikale items het Rice en kollegas (Oetting, Rice, en Swank 1995; Rice, Buhr, en Nemeth 1990; Rice, Buhr, en Oetting 1992; Rice, Oetting, Marquis, Bode, en Pae 1994) gevind dat STG-kinders op sogenaamde "fast-mapping"-take swakker as ouderdomkontroles vaar, met werkwoorde wat die mees problematies vir STG-kinders is. Volgens Leonard (1998:45) behels "fast mapping" die vaslegging van 'n inisiële assosiasie tussen 'n woord en die woord se referent ná slegs een of twee blootstellings aan die betrokke woord (cf. De Villiers, De Villiers, Roeper, Seymour, en Zurer Pearson 2003:113). STGkinders toon dus vertraagde leksikale ontwikkeling, maar hul leksikale vermoëns verskil ook in ander opsigte van dié van tipies-ontwikkelende kinders.

\subsection{Sintaksis}

\subsubsection{Vroeë sintaktiese strukture}

STG-kinders begin later as hul tipies-ontwikkelende eweknieë om twee-woord kombinasies te produseer. Wanneer die vertraagde aanvang van hul enkelwoord produksies in ag geneem word, is dit nie verbasend nie. Behalwe vir 'n vertraagde aanvang van ontwikkeling blyk daar geen verskil te wees tussen die twee-woord uitinge van STG-kinders en hul GLU-kontroles nie (Freedman en Carpenter 1976; Leonard, Bolders, en Miller 1976), maar hierdie is nie 'n aspek waaroor daar meer intensief navorsing gedoen word nie. 


\subsubsection{Vraagvorming}

Leonard (1995) het bevind dat STG-kinders minder geneig is om die hulpwerkwoord na 'n posisie in die sin voor die subjek te skuif tydens vraagvorming as wat GLU-kontroles is. STG-kinders produseer dus meer gereeld vrae soos * What I can eat $?^{4}$ in plaas van What can I eat? as hul GLU-kontroles.

\subsubsection{Passiewe konstruksies}

Volgens Van der Lely (1996) ervaar STG-kinders meer probleme as tipies-ontwikkelende kinders met die korrekte interpretasie van sogenaamde "vol" passiewe konstruksies (soos The dog is brushed by the girl), ook waar die twee groepe kinders dieselfde telling op 'n taaltoets behaal het. Hierdie STG-kinders is ook meer geneig om kort passiewe konstruksies (soos The dog is brushed) as 'n byvoeglike naamwoord konstruksie te interpreteer (een wat as the brushed dog geparafraseer kan word) in plaas van as 'n kort passiewe konstruksie, d.i., as 'n passiewe konstruksie sonder die voorsetsel- (by) frase. Soos Leonard (1998:59) uitwys: "Laasgenoemde interpretasie is natuurlik nie verkeerd nie, maar die verskil tussen die kinders dui moontlik daarop dat die STG-kinders 'n passiewe interpretasie vermy".

\subsubsection{Binding}

Volgens Van der Lely en Stollwerck (1997) ervaar STG-kinders probleme met die vasstel van bindingsverhoudings ${ }^{5}$ en daarom vind hierdie kinders dit moeilik om die referent van persoonlike en refleksiewe voornaamwoorde te bepaal onder omstandighede waarin hierdie kinders van slegs sintaktiese leidrade gebruik moet maak, d.i., waar hulle geen visuele of semantiese leidrade ontvang nie en waar hulle nie op hul kennis van die regte wêreld kan staat maak om die referent te bepaal nie. STG-kinders sal dit byvoorbeeld moeilik vind om te bepaal na wie her en herself in konstruksies soos Is Janice seeing her?, Charlotte thinks that Judy is washing herself, en The girl says that every ballerina is talking to herself verwys.

\subsubsection{Morfo-sintaksis}

Verskeie studies het aangetoon dat STG-kinders 'n laer persentasie grammatikale morfeme ${ }^{6}$ as hul ouderdomkontroles gebruik (cf. bv. Leonard, Bortolini, Caselli, McGregor, en Sabbadini 1992; Loeb en Leonard 1991; Ullman en Gopnik 1994). Behalwe vir die feit dat hierdie kinders grammatikale morfeme weglaat uit verpligte kontekste, gebruik hulle ook hierdie 
morfeme op 'n ontoepaslike wyse, d.i. hulle voeg hierdie morfeme in ontoepaslike kontekste in (cf. bv. Gopnik 1990a). Die voorbeeld You got a tape recorders uit Gopnik (1990a:147) dien as illustrasie van die ontoepaslike invoeging van 'n grammatikale morfeem, waar die meervoudsvorm van tape recorder gebruik word om na 'n enkele bandopnemer te verwys.

\section{$2.3 \quad$ Fonologie}

Leonard (1998:71) gee 'n oorsig van die studies van die fonologiese ontwikkeling en vermoëns van STG-kinders en kom tot die slotsom dat die meeste van hierdie studies óf geen kontrolegroep gebruik het nie óf van ouderdomskontroles gebruik gemaak het, maar dat relatief min van hierdie studies 'n kontrolegroep bestaande uit jonger, tipies-ontwikkelende kinders wat op een of ander taalmaatstaf (soos GLU) vergelykbaar met die STG-kinders was, ingesluit het. Waar geen kontrolegroep ingesluit is nie, is die vaardighede van die STGkinders wat bestudeer is, vergelyk met die vaardighede van jonger, tipies-ontwikkelende kinders soos aangetref in die literatuur. Hierdie probleme rondom die afwesigheid van kontroles asook die gebruik van gerapporteerde norme in plaas van self-verkreë resultate veroorsaak dat gevolgtrekkings oor die fonologiese vermoëns van STG-kinders as tentatief beskou behoort te word. Leonard se gevolgtrekking, gebaseer op die resultate van studies soos dié van Leonard (1982), is dat hierdie kinders meestal dieselfde fonologiese eienskappe toon as dié wat in jonger, tipies-ontwikkelende kinders waargeneem word.

\section{$2.4 \quad$ Pragmatiek}

Wanneer STG-kinders se gesprekke breuke toon, kan dit gewoonlik aan hierdie kinders se beperkte of afwykende fonologiese, leksikale, en/of morfo-sintaktiese vermoëns toegeskryf word. In sommige gevalle toon hierdie kinders egter pragmatiese vermoëns wat verskil van dié van tipies-ontwikkelende kinders, waar hierdie verskil nie aan fonologiese, leksikale, en/of morfo-sintaktiese beperkinge of afwykings toegeskryf kan word nie. Bishop, Chan, Adams, Hartley, en Weir (2000) het byvoorbeeld bevind dat STG-kinders minder geneig as tipies-ontwikkelende kinders was om op volwassenes se respons-ontlokkende uitinge te reageer en van nie-verbale response (soos kopknik en -skud, skouers optrek, of vingerwys na 'n referent) gebruik te maak. Die STG-kinders wat nie van nie-verbale response gebruik 
gemaak het nie, was ook dié met 'n groot hoeveelheid ontoepaslike response wat nie geredelik deur fonologiese, leksikale, en/of morfo-sintaktiese beperkinge of afwykings verklaar kon word nie. Hierdie ontoepaslike response het uitinge ingesluit wat die indruk geskep het dat die kind min aandag geskenk het aan wat deur die volwassene gesê is of dat die kind die volwassene se uiting verkeerd verstaan het, asook uitinge wat irrelevante inligting bevat het of wat prosodie ontoepasllik tot die konteks getoon het ${ }^{7}$. Voorbeelde van sulke ontoepaslike response (vertaal uit Bishop et al. 2000:198-199) sluit die volgende in:

(1) Volwassene: Het julle Blackpool toe gegaan met die motor?

Kind: Ja.

Volwassene: En wat van toe julle Liverpool toe gegaan het?

Kind: Dit was warm.

(2) Volwassene: Wat dink jy is fout met daardie speelding?

Kind: $\quad$ Ek dink dit kon dalk in die water geval het, op die sesde Januarie.

(3) Volwassene: Wat dink jy is fout met daardie seuntjie?

Kind: $\quad$ Ek hou môre my verjaarsdagpartytjie.

\subsection{Fokus in hierdie artikel}

STG-kinders toon almal 'n beduidende beperking in taalvermoë in die afwesigheid van onder andere die volgende (gewoonlik oorsaaklike) faktore: gehoorgestremdheid, lae tellings op nieverbale intelligensietoetse, emosionele versteurings, en/of neurologiese skade. Nietemin vorm hierdie kinders nie 'n homogene groep nie ${ }^{8}$ (Aram 1991:84-85), nóg wanneer STG-kinders vergelyk word met ander kinders van dieselfde taal, nóg wanneer STG-kinders oor tale heen vergelyk word. Ondanks hul heterogeniteit is daar een eienskap wat deur die meeste STGkinders gedeel word, en dit is dat hulle besonder swak vaar in die konvensionele gebruik van grammatikale morfeme. Die weglating/nie-weglating/invoeging van enige spesifieke grammatikale morfeem kan wispelturigheid toon selfs binne een en dieselfde linguistiese konteks. Verder blyk sommige morfeme disproporsioneel moeilik bemeesterbaar te wees. Om 
hierdie redes het die verklarings wat vir bespreking in hierdie artikel geselekteer is te make met STG-kinders se agterstande/afwykings in hul gebruik van grammatikale morfeme. Van hierdie verklarings kan egter die teenwoordigheid van sommige van die ander eienskappe van STG ook verduidelik, wat hierdie verklarings dan meer aantreklik maak as dié wat 'n verduideliking vir uitsluitlik afwykings in grammatikale morfologie kan gee.

\section{LINGUISTIESE VERKLARINGS}

Onder die eerste tipe verklaring, d.i., verklarings vir STG as gebrekkige linguistiese kennis, resorteer die voorstel, wat in afdeling 3.1 bespreek word, dat die agterstande van STG-kinders voortspruit uit 'n selektiewe gestremdheid in die vasstelling van die verhouding tussen afhanklike konstituente. Verdere voorstelle is dat STG-kinders vassteek in 'n vroeë dog normale stadium van die verwerwing van Tyds- ${ }^{9}$ en/of kongruensiemarkering ${ }^{10}$; en dat STGkinders probleme met funksionele kategorieë ervaar, voorstelle wat onderskeidelik in afdelings 3.2 en 3.3 bespreek word. Afdeling 3.4 handel oor die voorstel dat STG die resultaat is van gebrekkige markering van sommige grammatikale kenmerke (soos getal en persoon) wat weer lei tot die onvermoë om grammatikale reëls te verwerf, en afdeling 3.5 oor die voorstel dat STG-kinders grammatikale reëls slegs op 'n beperkte reeks kontekste toepas. Elk van die linguistiese verklarings word kortliks geëvalueer, en 'n samevatting van hierdie verklarings word in afdeling 3.6 gegee.

\subsection{Selektiewe Gestremdheid in Konstituent-skuiwing ("Representational Deficit for Dependent Relations")}

Die eerste linguistiese verklaring vir STG wat hier weergegee word, hoort tot 'n groep verklarings wat STG as 'n probleem met strukturele verhoudings beskou ${ }^{11}$. Van der Lely (1994) se verklaring vir STG, wat die "Representational Deficit for Dependant Relations" Hipotese of RDDR genoem word, is dat die agterstande van STG-kinders voortvloei uit 'n selektiewe gestremdheid in die daarstelling van die strukturele verhoudings tussen afhanklike konstituente, wat daartoe lei dat sekere konstituentskuiwe wat verplig is, in die grammatika van STG-kinders opsioneel is. 
Van der Lely (2003:126-128) verduidelik: Volgens Chomsky (1995) se bespreking van minimalistiese sintaksis is daar 'n basiese grammatikale operasie genaamd "Move", of "Skuif", wat plaasvind omdat sekere oninterpreteerbare grammatikale kenmerke gekontroleer ("checked") moet word ${ }^{12}$. As hierdie kenmerke nie gekontroleer word nie, sal die uiting, volgens die beginsel van Volle Interpretasie ("Full Interpretation") ${ }^{13}$, nie interpreteerbaar wees nie, d.i., die uiting sal ineenstort op een van die twee raakvlakke, Leksikale Vorm ("Lexical Form" of LF) of Fonetiese Vorm ("Phonetic Form" of PF), as die kenmerke van funksionele kategorieë nie gekontroleer word nie. In die sin The children played rugby het die INFL, wat die hoof van die infleksionele frase (IP) is, 'n oninterpreteerbare [+Tyd]-kenmerk wat deur die [+Verlede tyd]-kenmerk van played gekontroleer moet word, en daarom skuif played in die INFL-posisie van die sin in. Die INFL trek dus die [+Verlede tyd]-kenmerk, en daarmee saam die leksikale item wat daardie kenmerk bevat (in hierdie geval played) aan om sy eie kenmerk te kontroleer. Die behoefte aan uitspreekbaarheid dryf dus kenmerkkontrolering wat slegs deur Skuif moontlik gemaak word. Volgens Van der Lely (2003:126) kan dit ook soos volg gestel word: "'n afhanklike strukturele (sintaktiese) verhouding in 'n uiting word gevorm met die doel om grammatikale kenmerke geassosieer met leksikale items (of konstituente) te ... kontroleer ..." of, in wat Van der Lely (2003:126) "meer teorie-neutrale terme" noem, "hierdie sintaktiese afhanklikheid kom voor wanneer een sinskonstituent 'n 'susterkonstituent' 'soek' vir kenmerkkontrolering".

Volgens Van der Lely (2003:127) lê die onderliggende afwyking in STG nie in die totale afwesigheid van die operasie Skuif nie, maar in die opsionele implementering van dié operasie. Sy bespreek die moontlikheid dat daar twee beginsels by Skuif betrokke is. Die eerste beginsel, wat deur STG-kinders gehoorsaam word, is dat konstituente slegs skuif as hulle kenmerke het wat gekontroleer moet word of dan wat ander konstituente se kenmerke moet kontroleer. 'n Werkwoord met die kenmerk [+Verlede tyd] sal dus net na die INFL skuif as die INFL finiet (oftewel Tydsgemarkeerd) is, en dus 'n Tydskenmerk het wat gekontroleer moet word, en nie om enige ander rede nie. Omdat STG-kinders egter 'n probleem het om die afhanklike verhouding tussen verskillende konstituente vas te stel, en dus vas te stel waar die kenmerk gekontroleer kan word, sal STG-kinders nie noodwendig die konstituent na die korrekte sintaktiese domein skuif om sy kenmerke te laat kontroleer nie. Die werkwoord onder bespreking kan volgens Van der Lely (1996:246) byvoorbeeld, in die grammatika van 
STG-kinders, óf teen die finiete INFL óf teen 'n ander konstituent wat vir Tyd gemarkeer is (soos 'n bywoord van tyd, bv. gister), gekontroleer word. Die tweede beginsel, wat afwesig is in die grammatika van STG-kinders (Van der Lely 1998), is dat Skuif afgedwing word as die konstituent se kenmerke nog nie gekontroleer is nie. Die RDDR stel dit dat hierdie afwesigheid veroorsaak dat Skuif 'n opsionele operasie in STG is, en daarom word sommige kenmerke nie gekontroleer nie.

Evaluering. Volgens Van der Lely (2003:126, in druk, en elders) gebruik sy die minimalistiese program van Chomsky (1995 en later) om die taalafwykings van STG-kinders mee te verduidelik, maar is die RDDR nie verbind aan hierdie program nie. Die rede waarom die RDDR, wat oor 'n aantal jare ontwikkel is, verskeie hersienings ondergaan het, kan dus wees dat daar gepoog word om tred te hou met ontwikkelinge in minimalistiese sintaksis. Dit kom egter voor asof Van der Lely eklekties te werk gaan wanneer daar besluit word by watter beginsels van minimalisme sintaksis gehou gaan word. So byvoorbeeld word die volgende verduideliking vir STG-kinders se probleme met die interpretasie van (sommige tipes) passiewe konstruksies in Van der Lely (1996:267-8) gegee: "Die STG-kinders blyk 'n spesifieke probleem te hê ... met die voorstelling van die skuif van die interne argument na die subjekposisie waar dit kasus en sy tematiese rol kan ontvang." Wat die kasus aanbetref (wat in die huidige weergawe van minimalistiese sintaksis nie toegeken word nie, maar gekontroleer word $\left.{ }^{14}\right)$, kan 'n mens aanvoer dat Van der Lely in 1996 gewerk het met die sintaktiese teorie wat toe tot haar beskikking was. Dieselfde kan egter nie gesê word oor haar stelling dat die interne argument skuif om 'n tematiese rol te ontvang nie ${ }^{15}$, want daar word (sedert die vroegste weergawe van die Beginsels-en-Parameters benadering) aanvaar dat argumente hul tematiese rolle in die sinsposisie waarin hulle oorspronklik gegenereer is, ontvang, voordat enige Skuif-operasies plaasvind (Haegeman 1994:310; O'Grady 1997:289). Om dus te sê dat argumente nie sekere tematiese rolle kan ontvang nie omdat sulke argumente nie Skuif ondergaan nie, strook nie met die voorstelle van minimalistiese sintaksis (of enige vroeër Beginsels-en-Parameters voorstelle) nie. Van der Lely stel dit by meer as een geleentheid dat die RDDR 'n verklaring bied vir STG-kinders se probleme met die interpretasie van passiewe konstruksies (cf. bv. Van der Lely 1996:267, 2003:127, in druk). Haar stelling is egter net waar indien 'n voorstel wat teenstrydig is met 'n aspek van die sintaktiese teorie waarbinne sy 
werk, aanvaar word. Indien nie, kan die RDDR nie dié kinders se probleem met die interpretasie van passiewe konstruksies verklaar nie.

Van der Lely en Stollwerck (1997) is van mening dat die RDDR kan verklaar waarom STGkinders probleme het om bindingsverhoudings te verstaan, m.a.w. om te besluit wat die referent van voornaamwoorde en refleksiewe voornaamwoorde is in sinne soos Is Mowgli tickling him?, Baloo Bear says that Mowgli is tickling himself, en The boy says that every monkey is washing himself, waar daar van sintaktiese leidrade (en nie semantiese leidrade of regte-wêreld-kennis nie) gebruik gemaak moet word om te bepaal na wie/wat him en himself verwys. In hierdie geval voer die RDDR weer aan dat gebrekkige daarstelling van sintaktiese verhoudings die oorsaak van die probleme is. 'n Mens benodig kennis van die bindingsverhouding tussen voornaamwoorde, refleksiewe voornaamwoorde, en naamwoorde om te weet na wie/wat voornaamwoorde en refleksiewe voornaamwoorde kan verwys: 'n Refleksiewe voornaamwoord mag net verwys na 'n plaaslike voornaamwoord of na 'n plaaslike naamwoord. In Pieter sê Johan hou van homself mag homself net verwys na Johan (die plaaslike naamwoord, d.i., die naamwoord in dieselfde klous as homself) en nie na Pieter nie. 'n Voornaamwoord mag weer net verwys na 'n nie-plaaslike, ander voornaamwoord, na 'n nie-plaaslike naamwoord of na iets/iemand wat nie vantevore in daardie sin genoem is nie. In die sinne Pieter sê Johan hou van hom en Hy sê Johan hou van hom, mag die hom nie na dieselfde persoon as Johan verwys nie, maar wel na dieselfde persoon as Pieter (die nieplaaslike naamwoord) of as hy (die nie-plaaslike, ander voornaamwoord), of na enige ander manlike entiteit waarna nie deur Pieter of deur hy verwys word nie. Volgens die RDDR ervaar STG-kinders probleme met die interpretasie van hierdie tipe sinne omdat hulle 'n probleem het om sintaktiese verhoudings (soos bindingsverhoudings) daar te stel. Hierdie verduideliking is egter te vaag om verhelderend te wees, veral omdat dit nie duidelik gemaak word hoe hierdie probleem met interpretasie van bindingsverhoudings saamhang met die opsionaliteit van die tweede beginsel van die Skuif-operasie in die grammatika van STGkinders nie.

Wat die RDDR wel kan verklaar, is STG-kinders se probleme met die produksie van passiewe konstruksies en enige ander konstruksie waarby Skuif betrokke is, soos vraagsinne. Van der Lely self (1996:246) is van mening dat die RDDR kan verklaar waarom dit lyk asof STG- 
kinders kenmerke opsioneel gebruik en waarom hierdie opsionaliteit te make het met weglating in verpligte kontekste en nie met invoeging in ontoepaslike kontekste nie. Haar verduideliking is dat as die kenmerk Tyd gekontroleer word, dit korrek in die fonologiese vorm van die werkwoord gerealiseer word, maar as Tyd nie gekontroleer word nie, dit nie in die fonologiese vorm van die uiting sal verskyn nie en die werkwoord dus in die infinitiewe (d.i., nie-Tydsgemarkeerde) vorm sal verskyn. Dit is wel so dat STG-kinders kenmerke opsioneel foneties realiseer (m.a.w. dat die kinders soms 'n verpligte grammatikale morfeem uitspreek en soms nie), maar Van der Lely se verduideliking strook nie as daar aanvaar word dat leksikale items reeds-geïnflekteerd uit die leksikon herroep word nie. Indien laasgenoemde aanvaar word, is die fonetiese realisering van grammatikale kenmerke soos Tyd nie afhanklik van Skuif nie en sal die werkwoord slegs in die infinitiewe vorm verskyn indien dit in daardie vorm uit die leksikon herroep is. As die werkwoord in die Tydsgemarkeerde vorm herroep is, sal daardie vorm (en dus die verpligte grammatikale morfeem) voorkom, of Skuif plaasvind al dan nie. Verder is dit nie die geval dat STG-kinders grammatikale morfeme slegs opsioneel weglaat nie, maar ook dat hierdie kinders sulke morfeme opsioneel invoeg in ontoepaslike kontekste. Hiervoor bied die RDDR in sy huidige vorm geen verklaring nie ${ }^{16}$.

\subsection{Verlengde Opsionele Infinitief Hipotese ("Extended Optional Infinitive Account")}

'n Tweede linguistiese verklaring vir STG is dié van Rice, Wexler, en Cleave (1995). Hierdie navorsers en hul kollegas stel voor dat STG-kinders in 'n vroeë stadium van ontwikkeling van Tydsmarkering van werkwoorde bly. Tipies-ontwikkelende kinders gaan ook deur hierdie stadium, waartydens die gebruik van die infinitiewe vorm van die werkwoord vir hulle 'n opsie is in kontekste waarin die finiete vorm vereis word in die volwassene se grammatika, soos voorgestel deur Wexler (1994). Tipies-ontwikkelende kinders gaan dan egter voort na 'n meer gevorderde stadium waarin die finiete werkwoordvorme konsekwent in vereiste kontekste gebruik word. Daarenteen steek STG-kinders lank in die stadium van opsionele infinitiewe vas (vandaar die "Verlengde" in Rice, Wexler, en Cleave se benaming "Verlengde Opsionele Infinitief Hipotese"), en sommige van dié kinders vorder nooit verder as hierdie stadium nie. 
Om die bewerings van die Verlengde Opsionele Infinitief Hipotese te kan verstaan, moet 'n mens kyk na die besonderhede van wat Wexler (1994) voorstel in terme van tipiesontwikkelende kinders $^{17}$ : In die Opsionele Infinitief stadium laat kinders soms na om Tyd overt (deur 'n grammatikale morfeem) te markeer in hoofklouse (m.a.w. in klouse waarin Tydsmarkering verplig is). Die morfeme wat in Engels Tyd overt markeer, en wat soms in die Opsionele Infinitief stadium weggelaat word, sluit die volgende in (Rice en Wexler 1996:1241):

(i) die derdepersoon- enkelvoud $-s$, soos aangetref in She sings. Let egter daarop dat die meervoudsekwivalent, naamlik sing in They sing, ook 'n finiete (d.i., Tydsgemarkeerde) werkwoordvorm verteenwoordig, al word Tyd nie in hierdie geval overt aangedui nie. In She makes him sing is sing egter in die infinitiewe vorm (waar makes in die finiete of Tydsgemarkeerde vorm is) en so ook sing in She likes to sing (waar likes finiet of Tydsgemarkeerd is);

(ii) -ed, soos aangetref in She/They played the game;

(iii) BE-vorme, soos aangetref in She is teaching him, They are teaching him, en He was happy; en

(iv) DO-vorme, soos aangetref in They do spot him from time to time, waar die do beklemtoon word, of in She does not spot him. In hierdie voorbeelde word die DOvorme vir Tyd gemarkeer en is spot telkens in die infinitiewe (nie-Tydsgemarkeerde) vorm. Soos in (i) hierbo word finiete en infinitiewe werkwoordvorme dus soms in een en dieselfde uiting aangetref.

Een rede wat Wexler (1994:335) aanvoer vir die verskynsel dat 'n kind nalaat om Tyd overt te markeer, is dat die grammatikale kategorie $\mathrm{T}$ (Tyd), wat volgens die Verdeelde INFL Hipotese $^{18}$ ("Split INFL Hypothesis") van Pollock (1989) die hoof van die Tydsfrase (TP) is, vir die kind opsioneel is. As TP wel in 'n uiting teenwoordig is, sal die werkwoord vanuit die werkwoordfrase na die TP skuif sodat die werkwoord vir Tyd gemarkeer kan word. As TP egter nie teenwoordig is nie, sal die uiting as 'n infinitiewe sin beskou word. Die werkwoord sal dan nie na die TP skuif nie (want die TP bestaan nie) en sal gevolglik nie vir Tyd gemarkeer word nie. In hierdie geval sal die grammatikale Tydsmerker dus weggelaat word in die fonologiese vorm van die uiting en sal die infinitiewe vorm van die werkwoord eerder gebruik word (en om hierdie rede produseer STG-kinders gereeld uitinge soos *Yesterday we 
walk home, waar die grammatikale tydsmerker -ed weggelaat word, in plaas van Yesterday we walked home).

Volgens Rice en Wexler (1996:1240) is die term "weggelaat" hier 'n afkorting vir "nie ooglopend in die oppervlaksvorme nie", waar "oppervlaksvorme" na die fonologiese vorme verwys. Tegnies gesproke kan die afwesigheid van oppervlaks-Tydsmerkers toegeskryf word aan die feit dat die funksionele kategorie Tyd nie vir 'n bepaalde uiting daargestel word nie. Dit is dus nie die geval dat Tyd totaal afwesig is in die grammatika van STG-kinders en daarom altyd weggelaat word nie. Die kinders se grammatikas laat bloot uitinge met TPs asook uitinge daarsonder toe, terwyl die volwasse grammatika in hierdie konteks net uitinge met TPs as grammatikaal sou aanvaar. Van hier kom die "Opsioneel" in die benaming van Rice, Wexler, en Cleave se hipotese: die Tydsgemarkeerde fonologiese vorm is, vir 'n verlengde tydperk in vergelyking met tipies-ontwikkelende kinders, opsioneel in die grammatika van STG-kinders ${ }^{19}$.

Evaluering. Wexler (1994:335) se voorstel dat 'n werkwoord na die TP sal skuif as daar 'n TP in die afleiding is en in die infinitiewe vorm in die basisposisie (waar dit oorspronklik gegenereer is) sal bly as daar nie 'n TP is nie, m.a.w. die aanname waarop die Verlengde Opsionele Infinitief Hipotese berus, is problematies, en wel om twee redes. Die eerste is dat werkwoorde, soos vantevore verduidelik, reeds-geïnflekteerd uit die leksikon kom. Byvoorbeeld, walked word as 'n eenheid uit die leksikon herroep (en nie as walk en -ed wat dan saamsmelt nie), met sy [+Verlede tyd]-kenmerk, terwyl walk met sy [-Verlede tyd]kenmerk herroep word. Hierdie grammatikale kenmerke is semanties interpreteerbaar en hoef nie gekontroleer te word om te verhoed dat die afleiding ineenstort nie (Hornstein, Nunes, en Grohmann 2003:23). Wat wel ineenstorting sal veroorsaak, is as die semanties oninterpreteerbare [+/- Tyd]-kenmerk van die TP ongekontroleerd gelaat word. Dit beteken dat as daar geen TP is nie, die werkwoord nie sal skuif nie (nie overt of kovert nie - sien onder), maar dit beteken nie dat die werkwoord noodwendig in sy infinitiewe vorm sal verskyn nie. Laasgenoemde sal slegs die geval wees as die werkwoord in sy infinitiewe in plaas van in sy finiete vorm uit die leksikon herroep is. 
Die tweede rede waarom Wexler se voorgestelde Opsionele Infinitief stadium problematies is, het te make met die feit dat Wexler nie 'n duidelike onderskeid tussen overte en koverte Skuifoperasies maak nie. Daar word aangeneem dat die werkwoord wel na die TP sal skuif indien die TP in die afleiding aanwesig is. In sommige tale, soos Engels, skuif die werkwoord nie uit die werkwoordfrase voor Uitspel ${ }^{20}$ ("Spell-Out") nie, maar skuif die werkwoord wel kovert na die TP om, ná Uitspel, die TP se [+Tyd]-kenmerk te kontroleer. Kenmerkkontrolering word dus in hierdie geval in 'n taal soos Engels uitgestel tot ná Uitspel (Hornstein et al. 2003:13). Wat nodig is om werklik Wexler se voorstel oor die infinitiewe werkwoord vorm wat nie na die TP skuif nie, te verstaan, is dat Wexler dit duidelik maak waar hy na overte Skuif en waar na koverte Skuif of na beide ${ }^{21}$ verwys.

Wat die voorstel van Rice, Wexler, en Cleave betref, kan dit nie in sy huidige vorm interessante voorspellings maak oor en verklarings gee vir STG soos dit in morfologies verarmde tale presenteer nie. In Afrikaans, een so 'n taal wat arm is in terme van fleksiemorfologie, is die stamvorm van hoofwerkwoorde dieselfde as die infinitiewe vorm van hierdie werkwoorde en word daar nie fleksiemorfeme gebruik om Tyd of kongruensie aan te dui nie. In sulke tale kan die werkwoord dus in sy finiete of infinitiewe vorm voorkom (aangesien die twee vorme foneties dieselfde gerealiseer word), met of sonder ' $n$ TP in die afleiding. Om hierdie rede en omdat werkwoorde in tale wat wel van werkwoordmorfologie gebruik maak (soos in alle ander tale) in die reeds-geïnflekteerde vorm uit die leksikon herroep word, behoort bewyse vir die afwesigheid van 'n TP nie in die vorm van die aanwesigheid van infinitiewe vorme gesoek te word nie, maar eerder in die afwesigheid van overte werkwoordskuiwing in tale waarin sulke operasies wel overt voorkom - as daar geen TP is nie, kan die werkwoord steeds in die finiete vorm verskyn, maar kan die werkwoord nie na die TP skuif nie, aangesien dit nie daar 'n landingsplek het nie.

Alhoewel dit nie assulks deur Rice, Wexler, en Cleave gestel word nie (omdat hulle met 'n ander weergawe van minimalistiese sintaksis werk), kan die Uitgebreide Opsionele Infinitief Hipotese wel vir die volgende twee eienskappe van STG 'n verklaring bied: (i) woordvolgorde-afwykings in vraagsinne. As daar geen TP is waarheen die werkwoord kan skuif nie, dan behoort vraagvorme soos * What you will do? verwag te word; en (ii) die invoeging van Tydsmerkers in ontoepaslike kontekste. As die Tydskenmerk van die TP nie 
deur dié van die werkwoord gekontroleer word nie, dan is dit moontlik vir die werkwoord om die finiete vorm te hê waar die infinitiewe vorm verlang is (omdat daar geen Tydskenmerk is waarmee die werkwoord se Tydskenmerk hoef ooreen te stem nie).

Die eienskappe van STG wat nie deur die Uitgebreide Opsionele Infinitief Hipotese verklaar kan word nie, is (i) 'n laer persentasie gebruik van grammatikale morfeme. As werkwoorde met hul infleksie uit die leksikon herroep word, behoort die aan- of afwesigheid van 'n TP nie die werkwoordmorfologie te beïnvloed nie; (ii) probleme in die daarstelling van bindingsverhoudings; en (iii) probleme om passiewe konstruksies te interpreteer.

\subsection{Lat Ontwikkelende IP Hipotese ("Late Developing IP Hypothesis")}

Verskeie navorsers stel voor dat STG-kinders probleme ondervind met funksionele kategoriee ${ }^{22}$. Volgens Loeb en Leonard (1991) word dié probleme veroorsaak deur die afwesigheid van 'n IP wat lei tot die afwesigheid van subjek-werkwoord-kongruensie en van subjekkasus. Wat volg, is 'n uiteensetting van Loeb en Leonard se hipotese oor die kenmerke wat deur INFL toegeken word as daar binne die raamwerk van die Beginsels-en-Parameters benadering, maar nie binne die raamwerk van minimalistiese sintaksis nie, gewerk word.

In lyn met die Beginsels-en-Parameters benadering tot sintaksis, neem Loeb en Leonard aan dat die konstituent INFL die uiting se Tydskenmerke toeken. INFL kan óf die kenmerk [+Tyd] hê óf die kenmerk [-Tyd]. As INFL finiet is, d.i. die kenmerk [+Tyd] het, en die sin 'n hulpwerkwoord bevat, ontvang hierdie hulpwerkwoord dan die kenmerk [+Tyd] en word só vir Tyd gemarkeer. Byvoorbeeld, as die INFL finiet is, sal die hulpwerkwoord BE die kenmerk [+Tyd] ontvang en as is, are, was, of were (soos in She is/was jogging on the beach of We are/were thinking of you) uitgespreek word. As die INFL finiet is maar die uiting geen hulpwerkwoord bevat nie, sal die werkwoord die Tydskenmerk ontvang, en sal Tyd op die werkwoord aangedui word (soos in She jogged yesterday of She jogs every day).

INFL het ook kongruensiekenmerke, en ken hierdie kenmerke toe om toe te sien dat die subjek en die finiete werkwoord ooreenstemmende vorme het, byvoorbeeld dat die finiete vorm van die infinitief like as like uitgespreek word wanneer die subjek in die eerstepersoon- 
enkelvoud vorm is (soos in I like reading) en as likes uitgespreek word wanneer die subjek in die derdepersoon- enkelvoud vorm is (soos in He likes reading).

Behalwe Tyd- en kongruensiekenmerke, ken INFL ook nominatiewe kasus aan subjekte toe. Byvoorbeeld, in die uiting Sy sing altyd het die subjek nominatiewe kasus van die INFL af ontvang, en daarom is die uiting nie *Haar sing altyd (waar die subjek akkusatiewe kasus het) nie.

Omdat STG-kinders probleme het met sogenaamde "werkwoordmorfologie" asook met die korrekte kasustoekenning aan subjekte, beweer Loeb en Leonard (1991) dat INFL afwesig is in die grammatika van STG-kinders. Hulle baseer hul bewering onder andere op die werk van Radford (1988) met tipies-ontwikkelende kinders, waarin hy tot die slotsom kom dat dié kinders se vroeë uitinge geen INFL bevat nie aangesien die kinders geen kenmerke geassosieer met INFL foneties gerealiseer het nie.

Evaluering. Soos vantevore genoem, word daar binne die raamwerk van minimalistiese sintaksis aanvaar dat leksikale items met hul grammatikale kenmerke uit die leksikon herroep word. Kasus-, Tyd-, kongruensie- en ander kenmerke word dus nie toegeken nie, nie deur INFL nie en ook nie deur enige ander funksionele kategorie nie. Die feit dat STG-kinders se taal probleme met werkwoordmorfologie en kasustoekenning toon, sal dus nie volgens hierdie siening as evidensie vir die afwesigheid van 'n IP beskou kan word nie, want werkwoorde word met hul werkwoordmorfologie, en naamwoorde en voornaamwoorde met hul infleksies (onder andere met kasus) uit die leksikon herroep. Die werkwoord skuif dus nie na die INFLposisie om Tyds- en kongruensiekenmerke te ontvang nie; die werkwoord skuif om die oninterpreteerbare Tydskenmerke van die INFL te kontroleer. Indien daar egter nie 'n IP is nie, sal die werkwoord nie na die IP kan skuif om die INFL se Tydskenmerk te kontroleer nie. Soos tydens die evaluering van Rice, Wexler, en Cleave se hipotese in afdeling 3.2 genoem is, is wat op 'n afwesige IP sou kon dui, nie die afwesigheid van grammatikale morfeme nie, maar die afwesigheid van werkwoorde in die IP-posisie in tale soos Afrikaans waarin die werkwoord overt skuif (bv. in 'n konstruksie soos *Hulle my sien). 
Soos Rice, Wexler, en Cleave se voorstel bied Leonard en Loeb s'n 'n verklaring vir STGkinders se probleme met woordvolgorde in vraagsinne en vir die invoeging van Tydsmerkers in ontoepaslike kontekste, maar nie vir die laer persentasie gebruik van grammatikale morfeme, vir probleme met die daarstelling van bindingsverhoudings, en vir probleme om passiewe konstruksies te interpreteer nie.

\subsection{Kenmerk Agterstand Hipotese ("Feature Deficit Hypothesis")}

'n Vierde linguistiese verklaring vir STG is Gopnik (1994a) se Kenmerk Agterstand Hipotese, wat oorspronklik "die Kenmerk Blindheid Hipotese" ("Feature Blindness Hypothesis") en toe, in hersiende vorm, die "Implisiete Grammatikale Reël Agterstand" ("Implicit Grammatical Rule Deficit") genoem is (Gopnik 1990a, 1990b). Volgens Gopnik se hipotese is STG die resultaat van 'n agterstand in die markering van 'n spesifieke klas linguistiese kenmerke (wat getal, persoon, Tyd, aspek, en geslag insluit), 'n agterstand wat lei tot die onvermoë om implisiete grammatikale reëls te formuleer. Persone met STG wat Engels verwerf, sal byvoorbeeld nie die reël dat die werkwoord met 'n -s moet eindig as die subjek in die derdepersoon- enkelvoud vorm is, verwerf nie.

STG-kinders kan op twee maniere kompenseer vir die afwesigheid van hierdie implisiete reëls. Die eerste manier is deur blote memorisering ("rote learning"): Hulle moet geïnflekteerde vorme, byvoorbeeld played, leer, net soos hulle (en tipies-ontwikkelende kinders) moet leer dat bought, en nie buyed nie, die verledetydsvorm van buy is. Waar tipiesontwikkelende Engelssprekende kinders dus onbewustelik uitwerk dat -ed agteraan die werkwoord gevoeg word om die verledetydsvorm van die werkwoord te vorm en daarom slegs die onreëlmatige vorme soos saw en went hoef te memoriseer, moet STG-kinders elke stam (soos play) asook elke geïnflekteerde vorm (plays, played, playing) memoriseer. Die tweede manier waarop STG-kinders kan kompenseer vir die afwesigheid van implisiete reëls is deur reëls waarin hulle eksplisiete onderrig ontvang het, toe te pas. Wanneer STG-kinders kognitief volwasse genoeg is, kan hulle in 'n klaskamer- of terapiesituasie reëls eksplisiet leer (bv. "voeg 'n -s by as daar meer as een is") en hierdie reëls dan toepas (Paradis en Gopnik 1994:146). 
Volgens Gopnik is dit nie te sê dat 'n bepaalde kenmerk altyd aangetas sal blyk te wees wanneer 'n mens na die fonologiese vorm van die uiting kyk nie. Dit sal eerder die geval wees dat daar geen bewyse is dat die fonologiese vorm van die morfeem, waar dit wel verskyn, inderdaad die kenmerk reflekteer nie. Die fonologiese vorm van die multimorfemiese woord kan dus vir die persoon met STG 'n ongeanaliseerde eenheid wees. Gopnik (1994a:77) verskaf die volgende voorbeeld ('n geskrewe uiting deur 'n persoon met STG) wat haar punt illustreer: On Saturday I got up and I wash myself and I get dress and I eat my breakfast and I watched TV all day and I went to bed. Uit die fonologiese vorm van drie van die ses werkwoorde in hierdie uiting skyn dit dat die persoon weet hoe om die verledetyd grammatikaal aan te dui in Engels, maar die afwesigheid van verledetydsmarkering op die ander drie werkwoorde laat die vraag ontstaan of watched nie eerder bloot 'n gememoriseerde vorm is nie (soos wat die onreëlmatige vorme got up en went vir alle sprekers van Engels gememoriseerde vorme is).

Om die bespreking bondig te hou, word die empiriese ondersteuning vir die verklarings van STG nie in hierdie artikel weergegee nie. In Gopnik se geval sal daar egter 'n uitsondering gemaak word, aangesien die proefpersone in die studie waarop sy haar hipotese grond, besonder interessant is: Gopnik (1990b, 1994b) voer die resultate van die studie van 'n familie wat oor drie generasies strek aan ter ondersteuning van haar hipotese. Sy en haar kollegas het 'n battery van 14 toetse uitgevoer op die 30 familielede (een ouma, haar vyf kinders, en haar 24 kleinkinders), en ook monsters van hul spontane taalgebruik (geskrewe en gesproke) geanaliseer. Daar is bevind dat 16 van die familielede (die ouma, al drie haar dogters, een van haar twee seuns, ses van haar 13 kleindogters, en vyf van haar 11 kleinseuns) beduidend swakker as die res gevaar het op die vier toetse wat sintakties-semantiese vermoëns geëvalueer het, maar nie op die ander 10 toetse nie. Gopnik (1990b:715) noem as voorbeeld dat die twee groepe familielede nie beduidend verskil het in hul reaksies op toetse van kennis van besitlike relasies (The baby's mother vs. The mother's baby) ${ }^{23}$, refleksiewe voornaamwoorde (He washes him vs. He washes himself) $)^{24}$, en negatiewe passiewe konstruksies (The car is not being pulled by the truck $)^{25}$ nie. Die twee groepe het egter beduidend verskil onder andere in hul vermoëns om Tyd te verander (soos as hulle gevra word om die laaste sin te voltooi: Every day he kisses his nanny. Yesterday he ___), en om die meervoud van onsinwoorde (soos zat) te verskaf (cf. ook Goad en Rebellati 1994; Gopnik 1994a; Ullman en Gopnik 1994). Uit die resultate van hierdie studies blyk dit dat die 
familielede met STG nie implisiete grammatikale reëls verwerf het nie en dat, waar hulle wel tydens toetsing die korrekte oppervlaksvorm van woorde (soos werkwoorde in die verledetydsvorm en naamwoorde in die meervoudsvorm) verskaf het, hulle gebruik gemaak het van vorme wat hulle gememoriseer het.

Evaluasie. Gopnik se voorstel bied 'n verklaring vir die ontoepaslike weglating sowel as die ontoepaslike invoeging van grammatikale morfeme. Waarvoor haar voorstel nie 'n verklaring bied nie, is woordvolgorde-afwykings in vraagsinne; probleme in die daarstelling van bindingsverhoudings; en probleme om passiewe konstruksies te interpreteer, laasgenoemde wat volgens Gopnik (1990b) nie 'n probleem vir persone met STG is nie.

\subsection{Noue Reëlverwerwing ("Narrow Rule Learning")}

In teenstelling met Gopnik en haar kollegas wat van mening is dat STG-kinders nie implisiete reëls onbewustelik formuleer en verwerf nie, stel Ingram en Carr (1994) dit dat hierdie kinders wel implisiete reëls kan verwerf, maar dat hulle (i) hierdie reëls laat verwerf in vergelyking met hul tipies-ontwikkelende eweknieë en (ii) dié reëls, nadat hulle wel verwerf is, op 'n beperkte reeks linguistiese kontekste toepas, vandaar die benaming "Noue Reëlverwerwing" vir Ingram en Carr se hipotese. Dié hipotese is gegrond op die werk van Morehead en Ingram, wat reeds in 1973 STG-kinders se probleem met grammatikale morfologie as volg gestel het:

Om op te som, linguisties afwykende kinders ontwikkel nie bisarre linguistiese sisteme wat kwalitatief anders is as dié van normale kinders nie. Hulle ontwikkel eerder soortgelyke linguistiese sisteme met 'n opmerklike vertraging in die aanvang en verwerwingstyd. Wat meer is, wanneer die linguistiese sisteme ontwikkel is, gebruik afwykende kinders (sic) hulle nie so kreatief soos normale kinders vir die produsering van hoogs gevarieerde uitinge nie (p. 344).

Die nosies 'beperkte reeks linguistiese kontekste' en 'nie so kreatief ... nie' spruit onder andere uit empiriese data wat daarop dui dat STG-kinders (i) alle sintaktiese konstruksies kan gebruik wat deur tipies-ontwikkelende kinders gebruik word, maar dat daar sekere transformasiereëls 
(om die terminologie van 1973 te gebruik) is wat beduidend minder gereeld deur STG-kinders toegepas word, byvoorbeeld subjek-hulpwerkwoord-inversie in vraagvorme, sodat Will she play? as She will play? geproduseer word, en werkwoord-partikel-skuif, sodat You pick it up as You pick up it geproduseer word (Morehead en Ingram 1973); en (ii) meer beperk was in die reeks sintaktiese reëls wat hulle gebruik het as in hul gebruik van grammatikale morfologie (Ingram en Carr 1994). Leonard (1998:229) verwys ook na studies oor fonologie en oor die betekenis van twee-woord uitinge, waarvan die bevindinge konsekwent is met die verklaring van die noue verwerwing van reëls as oorsaak van STG, asook na terapieresultate wat daarop dui dat STG-kinders die reëls waaraan hulle tydens terapie blootgestel is, stapsgewys veralgemeen, en nie drasties afwyk van die voorbeelde wat hulle tydens die behandelingsessies teëgekom het nie.

Evaluasie. Buiten die feit dat daar nie meer in die raamwerk van minimalistiese sintaksis met transformasiereëls gewerk word nie, is die hoofkritiek teen Ingram en Carr se voorstel dat dit te vaag is om werklike verklarings vir die eienskappe van STG te gee. Oor enige van die eienskappe van STG (soos weglating van grammatikale morfeme en probleme met die daarstelling van bindingsverhoudings, woordvolgorde in vraagsinne, en interpretasie van passiewe konstruksies), met die uitsondering van die ontoepaslike invoeging van grammatikale morfeme, kan daar gesê word dat die STG-kind die "reël" ken, maar dit nie oral toepas waar dit toegepas behoort te word nie. Die vraag wat egter ontstaan, is wáárom hierdie kinders nie die reëls wat hulle ken, altyd toepas waar dit toegepas behoort te word nie. Op hierdie vraag gee Ingram en Carr geen antwoord nie.

\subsection{Samevatting: Linguistiese verklarings}

Elk van die vyf linguistiese verklarings wat hierbo bespreek is, poog om die kenmerkende probleme wat STG-kinders met grammatikale morfologie, en in besonder die toekenning (of kontrolering) van Tyds- en kongruensiekenmerke, het te verklaar. Elk van hierdie verklarings het egter tekortkominge. Sommige van die tekortkominge is verklaring-intern, wat meestal toe te skryf is aan die feit dat die navorsers met wat tans verouderde weergawes van sintaktiese teorie is, gewerk het (soos die geval is met die verklarings van veral Leonard en Loeb asook Ingram en Carr) of dat die aannames van sintaktiese teorie onakkuraat geïnterpreteer word 
(soos Van der Lely wat die posisie waarin tematiese rolle aan konstituente toegeken word, onakkuraat interpreteer). Ander tekortkominge van dié verklarings het te make met hul onvermoë om alle eienskappe van STG wat met taalstruktuur te make het, toereikend te verklaar. Verder noem Leonard (1998:235) dat "die Achilleshiel van die meeste van hierdie [linguistiese - FS] verklarings is dat hul voorspellings net vir 'n beperkte reeks tale geld". Daar is dus nog nie bewys dat die linguistiese verklarings vir STG wat hier aangebied is, enige mate van universaliteit het nie.

\section{PROSESSERINGSVERKLARINGS}

Sommige prosesseringsverklarings stel voor dat STG-kinders probleme ondervind om die grammatikale morfeme van sommige tale waar te neem, 'n voorstel wat in afdeling 4.1 bespreek word. Ander stel dit dat STG-kinders, ongeag die taal wat hulle praat, grammatikale gestemdhede toon, maar dat hierdie gestremdhede se omvang afneem soos die rykheid van die fleksiemorfologie van die betrokke taal toeneem. Dié voorstel word in afdeling 4.2 bespreek. Beide tipe prosesseringsverklarings voorspel dat STG-kinders se prosesseringsprobleem hul verwerwing van grammatikale morfologie sal kniehalter, maar ook dat die ontplooiing van die morfologie wat reeds verwerf is, negatief beïnvloed kan word deur hierdie prosesseringsprobleme (Bortolini, Leonard, en Caselli 1998:3). In teenstelling met die prosesseringsverklarings wat elk indiwidueel geëvalueer is, word die twee prosesseringsverklarings saam geëvalueer, en wel in afdeling 4.3, aangesien grootliks dieselfde kritiek teen albei gerig kan word.

\subsection{Oppervlak Hipotese ("Surface Hypothesis")}

Een prosesseringsverklaring is Leonard $(1989,1998)$ se Oppervlak Hipotese. Hierdie hipotese word só genoem omdat dit fokus op die perseptuele (d.i., oppervlaks-) eienskappe van morfeme, spesifiek die grammatikale morfeme van Engels.

Die voorstel is spesifiek dat Engelssprekende STG-kinders probleme ondervind om grammatikale morfeme waar te neem weens die akoestiese, oftewel perseptuele, eienskappe (soos die kort duur en die tekort aan opvallendheid) van sulke morfeme. Hierdie probleme 
met persepsie bemoeilik die verwerwing van dié morfeme. Die Engelse morfeme wat volgens hierdie hipotese moeilik is om waar te neem en aan te leer sluit $-s$ (as derdepersoonenkelvoud merker en as meervoudsmerker), -ed, besitlike 's, koppelwerkwoorde, hulpwerkwoordvorme van $B E$, infinitiewe to, en die komplementeerder that in, terwyl -ing se duur dit relatief maklik waarneembaar en verwerfbaar maak.

Volgens Leonard (1998:248) mag STG-kinders wel daartoe in staat wees om soortgelyke onbeklemtoonde sillabes in woorde wat uit een morfeem bestaan asook soortgelyke woordfinale konsonante (d.i., onbeklemtoonde sillabes en konsonante wat net soos grammatikale morfeme klink) waar te neem. Hiermee bedoel hy dat STG-kinders byvoorbeeld die woordfinale $[\mathrm{z}]$ in cheese maklik sal kan waarneem (maar nie noodwendig die woordfinale $[\mathrm{z}]$ in sees nie) asook die onbeklemtoomde [əd] in die monomorfemiese wicked (maar nie noodwendig die [əd] in die stam+verledetydsmerker needed nie). Die oppervlakseienskappe van hierdie klanke en sillabes stel egter groot eise aan STG-kinders se (voorgestelde) beperkte prosesseringskapasiteit, ongeag van die betekenis wat dié klanke en sillabes oordra (d.i., ongeag daarvan of hierdie klanke en sillabes morfeme is al dan nie). Die rede waarom hierdie fonologiese vorme moeiliker waargeneem word wanneer hulle grammatikale morfeme is, is omdat addisionele operasies dan uitgevoer moet word, naamlik (i) die opstel van 'n hipotese oor wat die grammatikale funksie van 'n vorm soos [z] en [əd] is en (ii) plasing van die vorm in 'n morfologiese paradigma ${ }^{26}$. Hierdie operasies, wat bo en behalwe die waarneming van die fonologiese vorme moet plaasvind wanneer dié vorme grammatikale morfeme is, moet boonop gou genoeg uitgevoer kan word om aan die res van die uiting aandag te kan gee en dit te kan waarneem en prosesseer.

Kortom gestel: STG-kinders ondervind probleme in die prosessering van talige toevoer wanneer dié toevoer nie-opvallende fonologiese segmente bevat. Weens hierdie verhoogde prosesseringslading is die kinders nie daartoe in staat om waargenome inligting te gebruik om morfologiese paradigmas daar te stel nie. ' $n$ Beperking in prosesseringskapasiteit het 'n groot nadelige effek op die gesamentlike operasies van waarneming van grammatikale morfeme en die opstel van hipoteses oor hul grammatikale funksie. Om hierdie rede sal dié morfeme baie gereeld gehoor moet word voor hulle verwerf word. 
Die vraag wat ontstaan, is waarom perseptuele eienskappe aan prosessering verwant moet wees, aangesien persepsie te make het met of materiaal voldoende geregistreer word al dan nie, terwyl prosessering te make het met mentale operasies wat uitgevoer word op materiaal wat reeds geregistreer is. Volgens Leonard (1998:250) is daar twee antwoorde op hierdie vraag. Die eerste is dat geregistreerde materiaal verlore kan gaan wanneer addisionele prosesseringsoperasies verlang word, en die tweede is dat prosesseringsbeperkinge in der waarheid mag verhoed dat materiaal waargeneem word.

\subsection{Morfologiese Rykheid Hipotese ("Morphological Richness Hypothesis")}

'n Tweede prosesseringsverklaring vir STG is dié van Morfologiese Rykheid (van onder meer Linder en Johnston 1992), waarvolgens STG-kinders van alle tale grammatikale gestremdhede toon, maar hoe ryker die fleksiemorfologie van hul taal is, hoe kleiner is hierdie gestremdhede. Soos Bortolini et al. (1998:3) dit stel: STG-kinders wy hul beperkte bronne aan die dominante grammatikale leidrade in die taaltoevoer (in Engels sal hierdie leidrade die woordvolgorde wees), wat min bronne oorlaat vir die prosessering van inligting wat deur ander grammatikale middele (soos grammatikale morfeme in Engels) verskaf word.

In tale soos Italiaans en Hebreeus het naamwoorde, werkwoorde, en byvoeglike naamwoorde altyd infleksie wat bydra tot hul betekenis; anders as in Engels kan hierdie woorde nooit as ongeïnflekteerde dog grammatikale stamme verskyn nie. Linder en Johnston se voorspelling is dat 'n kind met STG wat Italiaans, Hebreeus, of 'n soortgelyk morfologies ryk taal verwerf, op hierdie verpligte fleksiemorfeme sal fokus, ten spyte van die kind se beperkte linguistiese vermoëns. 'n Kind met STG wat egter Engels verwerf, sal eerder aan meer "betroubare" leidrade (soos woordvolgorde) aandag skenk as aan die fleksiemorfologie van die taal, want ongeïnflekteerde stamme is nie altyd (soos in die geval van Italiaans en Hebreeus) ongrammatikaal nie. Byvoorbeeld, in die grammatikale sin We eat a lot of fish kom eat sonder enige fleksiemorfeem voor. Hierteenoor is *He eat a lot of fish wel ongrammatikaal, maar daar kan van die woordvolgorde afgelei word wie vir wie eet, en die betekenis van *He eat a lot of fish is steeds duidelik, ondanks die afwesige fleksiemorfeem -s. 


\subsection{Evaluering en samevatting: Prosesseringsverklarings}

Verskeie outeurs (onder wie Gopnik 1994a, 1994c) is van mening dat die beskrywende en verduidelikende meriete van prosesseringsverklarings vir STG beperk is ${ }^{27}$. Daar is sekere algemene eienskappe van die taal van Engelssprekende STG-kinders wat nie deur die hipoteses aangespreek word nie, soos probleme met bindingsverhoudings en die interpretasie van passiewe sinne. 'n Verdere eienskap is die vervanging van $I$ met me, wat nie aan die duur van die morfeme of aan die graad van morfologiese rykheid toegeskryf kan word nie. Hiermee saam hang die verskynsel dat STG-kinders grammatikale morfeme in ontoepaslike kontekste invoeg. Nog 'n eienskap is laer subjek-hulpwerkwoord-inversie in vraagsinne: As beide die subjek en die hulpwerkwoord wel waargeneem en geproduseer word, ontstaan die vraag watter verduideliking, in terme van perseptuele eienskappe en/of morfologiese rykheid van Engels, gegee kan word vir die feit dat hierdie inversie min plaasvind. Verdere eienskappe van die taal van Engelssprekende STG-kinders is probleme met onreëlmatige verledetydsvorme en 'n voorkeur vir die saamgetrekte (en dus verkorte en gevolglik moeiliker waarneembare) vorme van morfeme (soos 's in it's in plaas van is in it is), wat weer eens nie aan perseptuele eienskappe toegeskryf kan word nie. Laastens spreek die prosesseringsverklarings nie die feit aan dat verskillende morfeme met identiese fonetiese waardes (soos die derdepersoon- enkelvoud $-s$ en die besitlike $-s$ ) nie vir STG-kinders ewe moeilik is nie. As morfeme dieselfde klink, behoort die STG-kinders dieselfde mate van probleme met dié morfeme te ervaar, en dit blyk nie die geval te wees nie.

Kritiek wat net teen die Oppervlakshipotese, en nie teen die Morfologiese Rykheid Hipotese nie, gerig kan word, het te make met die tipe morfeme wat volgens Leonard $(1989,1998)$ as lank beskou word. So byvoorbeeld is -ing een van die morfeme wat volgens Leonard 'n lang duur het en daarom relatief maklik verwerfbaar is. Tog word -ing in baie dialekte van Engels tot ' $\mathrm{n}$ sillabiese [n] verkort, wat dit moeilik maak om in te sien hoe -ing dan langer is as byvoorbeeld is, were, en that.

Dit is voor die hand liggend dat die voorspellings wat hierdie twee hipoteses vir een taal maak, nie noodwendig vir 'n ander taal sal geld nie. Nie een van die twee prosesseringsverklarings hou dus belofte in as die oogmerk is om ' $\mathrm{n}$ enkele verklaring vir STG 
daar te stel nie. Die slotsom waartoe Bortolini et al. (1998:18) kom, nadat hulle hierdie twee prosesseringsverklarings vir STG teen Engelse en Italiaanse data getoets het, is dat dit nie duidelik is of enige een van die twee uiteindelik bevredigend sal blyk te wees nie. Dit mag wees dat die fonetiese eienskappe van die toevoer wat kinders ontvang, tog STG-kinders feller belas as tipies-ontwikkelende kinders, maar tot op hede is daar nog nie oortuigende argumente vir hierdie aanname aangevoer nie.

\section{MOONTLIKE BYDRAE VAN DIE BESTUDERING VAN STG IN AFRIKAANSSPREKENDE KINDERS}

Ravid, Levie, en Ben-Zvi (2003:187-188) beklemtoon die belang van diversiteit wanneer die linguistiese vaardighede van STG-kinders bestudeer word. "Diversiteit" verwys hier enersyds na die sogenaamde "linguistiese sisteme" (begrip en produksie van infleksie van naamwoorde en werkwoorde, van afleidingsmorfeme, en van opsionele gebonde fleksiemorfeme) binne een en dieselfde populasie, d.i., binne STG-kinders van dieselfde taal. Andersyds verwys "diversiteit" na verskillende tale, waar die impak van taaltipologie (bv. hoë vs. lae infleksietale) op die presentering van simptome van STG ondersoek kan word.

Eers onlangs het navorsers begin om kruislinguistiese data te ondersoek tydens die opstel en evaluering van verklarings vir STG. Hierdie kruislinguistiese data is egter nog baie beperk, beide in terme van die aantal studies en in terme van die tale waarteen die teoretiese verklarings vir STG al getoets is. Hierdie tale sluit Duits, Engels, Frans, Grieks, Hebreeus, Italiaans, Japannees, Nederlands, Sweeds, Kroasies, Hongaars, Inuktitut, en Spaans ${ }^{28}$ in, waar daar oor die laaste vier tale meestal slegs 'n enkele studie rakende STG gepubliseer is. Tot op hede het geen verklaring Afrikaans ingespan nie, en geen verklaring is tot dusver getoets vir sy verklarende en voorspellende meriete rakende STG soos dit in Afrikaanssprekende kinders voorkom nie.

In Afrikaans word baie min grammatikale kenmerke foneties gerealiseer ${ }^{29}$. Afrikaans toon ook meer woordvolgordevariasie as, byvoorbeeld, Engels. Die beperkte fonetiese realisering van grammatikale kenmerke en die overte skuif van sintaktiese konstituente in Afrikaans makk hierdie taal uit ' $n$ teoretiese perspektief ' $n$ interessante een om te bestudeer wanneer daar 
na die eienskappe van STG gekyk word. Die vraag ontstaan: As STG-kinders probleme ervaar met grammatikale (fleksie-) morfeme, hoe presenteer STG in 'n taal waarin fleksiemorfeme in elk geval tot 'n baie beperkte mate voorkom (m.a.w. in 'n taal waarin baie min grammatikale kenmerke foneties gerealiseer word), maar waarin overte Skuif (wat te make het met die kontrolering van grammatikale kenmerke) gereeld voorkom?

'n Studie van STG in Afrikaanssprekende kinders sou op twee maniere kon bydra tot die (relatief beperkte) kennisbasis oor STG. Eerstens het Afrikaans eienskappe (soos morfologiese armoede in terme van fleksie) wat nuttig kon wees vir die toets van teoretiese verklarings vir STG wat op 'n ander taal gebaseer is. Daarom sou 'n studie van STG soos dit in Afrikaans presenteer nuwe lig kon werp op die verduidelikende meriete van die verskillende teoretiese verklarings vir STG en daardeur kon bydra tot die proses waardeur die aantal onakkurate teoretiese verklarings vir STG verminder word. Tweedens sou só 'n studie data kon verskaf wat nuttig is vir kliniese gebruik, d.i., vir die evaluering en behandeling van Afrikaanssprekende kinders wat STG het. Aangesien daar tot op hede geen omvattende studie gedoen is oor hoe STG in Afrikaans presenteer nie, sou sulke data die resultaat van pionierswerk wees. Hier word spesifiek gedink aan die ontdekking van 'n kliniese merker van STG in Afrikaans. Na aanleiding van Wexler (2003:54) kan só 'n merker beskryf word as "X (die afwesigheid/vervanging van 'n grammatikale morfeem, die afwesigheid van 'n sintaktiese operasie, of iets dergeliks) waarvoor daar bykans geen oorvleueling op enige gegewe relevante ouderdom tussen tipies-ontwikkelende kinders en STG-kinders vir die algehele voorkoms van X is nie". Wexler (2003:54) noem dat dit essensieel is om 'n korrekte en sensitiewe kliniese merker te hê om STG in kinders te identifiseer, om wetenskaplike sowel as om praktiese redes (cf. ook Conti-Ramsden en Hesketh 2003).

In die lig van die voorafgaande bespreking blyk dit dat 'n studie van STG soos dit in Afrikaanssprekende kinders presenteer, van beide wetenskaplike en kliniese belang sal wees. Só 'n studie sou eerstens die taalbegrip en -produksie van Afrikaanssprekende STG-kinders moet ondersoek om vas te stel watter eienskappe STG in Afrikaans toon. 'n Teoretiese verklaring sou dan vir hierdie eienskappe gevind moet word. In hierdie verband sou die bestaande teoretiese verklarings vir STG, onder andere die prominentes wat in hierdie artikel bespreek is, geëvalueer kon word in terme van hul verduidelikende meriete aangaande die 
eienskappe van STG soos aangetref in die taal van Afrikaanssprekende kinders. Gewapen met die kennis van hoe STG in Afrikaans presenteer en hoe hierdie presentering teoreties verklaar kan word, sou daar dan vasgestel kon word (i) op watter maniere Afrikaanssprekende kinders se taalbegrip en -gebruik geëvalueer moet word om STG te kan identifiseer (insluitende watter vaardighede deur taaltoetse geteiken behoort te word as die toetse ten doel het om Afrikaanssprekende taalgestremde kinders te onderskei van tipies-ontwikkelende kinders wat 'n nie-standaard variëteit van Afrikaans praat) en (ii) watter tipe terapiemetodes mees effektief sal wees wanneer Afrikaanssprekendes vir STG behandel word. Dit sal die professie in staat stel om die geskiktheid van hul huidige kliniese praktyke te evalueer en, waar nodig, aan te pas.

\section{SLOTBESPREKING}

In die literatuur is daar verskeie raminge van die algemeenheid van voorkoms van STG. Hierdie raminge wissel van 1.5\% (Tower 1979) tot tussen 6 en 8\% (American Psychiatric Association 1994). Die rede vir die groot variasie in raming is dat die meeste studies ontwerp is om die algemeenheid van voorkoms van alle vorme van taalgestremdheid, en nie spesifiek STG nie, onder kinders te bepaal. Dit bring mee dat sommige van die kinders wat in die raminge ingesluit is, eintlik voldoen aan die uitsluitingskriteria vir STG, soos gehoorverlies of swak prestasie op nie-verbale intelligensietoetse. Omdat die resultate van die taaltoetse soms gegee word sonder 'n aanduiding van die kinders se prestasie op ander metings, is dit moeilik om te bepaal hoeveel van die kinders wat taalprobleme getoon het, inderdaad STG gehad het. In 'n onlangse studie wat spesifiek daarop gemik was om die algemeenheid van voorkoms van STG vas te stel is bevind dat 'n beraamde $7.4 \%$ van alle 5 -jariges ( $8 \%$ van seuns en $6 \%$ van meisies) STG het (Tomblin, Records, Buckwalter, Zhang, Smith, en O'Brien 1997:1255). STG is langdurig van aard; tot $40 \%$ van pre-primêre kinders wat met STG geïdentifiseer word, toon steeds beduidende taalprobleme 4 tot 5 jaar ná pre-primêr (Aram en Nation 1980:167). Dit beteken dat 'n aantal (moontlik 3\%) skoolgaande kinders steeds met STG

presenteer. Die effek van STG op akademiese bedrywighede is wyd gedokumenteer ${ }^{30}$. Met beter begrip van STG mag dit moontlik wees om STG-kinders op meer effektiewe maniere te remedieer (en op maniere wat sal lei tot die beperking van STG se negatiewe invloed op hul akademiese vaardighede vroeër in die skoolloopbaan van hierdie kinders). Soos Leonard 
(1998:8) noem, "As daar geen ander voordele [van die studie van STG - FS] sou wees nie, sou hierdie moontlikheid voldoende regverdiging wees vir die beoefening van hierdie werk".

Daar is egter ander voordele aan die studie van STG, onder andere die bydrae tot 'n beter begrip van ander, nie-STG-, taalprobleme. Aangesien STG-kinders per definisie geen ander gestremdhede het nie, kan hul taalvermoë dien as grondlyndata vir enige ander gestremde populasie wat 'n taalgestremdheid, maar ook ander gestremdhede soos neurologiese afwykings of gehoorgestremdheid, het.

'n Derde rede vir die bestudering van STG het te make met die insigte wat só 'n studie kan bied in die aard van die menslike taalfakulteit. Die sentrale doel van sintaktiese teorie is om 'n omvattende verklaring te bied vir die eienskappe van menslike taal. Dit is 'n redelike aanname dat só 'n teorie ook vir STG verklarings moet kan gee, aangesien STG tog 'n vorm van menslike taal is. Die bestudering van STG kan dus bydra tot ons kennis en begrip van die aard van menslike taal en mag tekortkominge van huidige sintaktiese teorie ontbloot en sodoende op 'n indirekte wyse 'n bydrae lewer tot die hersiening van die teorie.

Navorsers gaan voort met die voorstel en verfyning van hipoteses oor STG. Hierdie hipoteses moet egter aan ten minste die volgende twee vereistes voldoen: (i) hulle moet teoreties gefundeer wees en (ii) hulle moet die data, d.i. die eienskappe van STG, kan verklaar. Soos in hierdie artikel aangedui, is daar verskeie hipoteses oor STG, maar neem hierdie hipoteses nie altyd die nuutste ontwikkelinge in sintaktiese teorie en data van meer as een taal in ag nie. As daar binne die raamwerk van minimalistiese sintaksis gewerk word, mag dit moontlik wees om aan te toon dat STG-kinders se probleme met grammatikale morfeme en met die skuif van sintaktiese konstituente verwant is en mag 'n toereikende verklaring, een wat STG as 'n probleem met grammatikale kenmerke beskou, voorgestel word. Aan die een kant kan daar probleme wees met die bestaan al dan nie van hierdie grammatikale kenmerke in die grammatika van STG-kinders. Aan die ander kant mag die probleem lê by die vereiste dat semanties oninterpreteerbare grammatikale kenmerke gekontroleer moet word deur middel van die skuif van leksikale items om sodoende te voorkom dat 'n afleiding ineenstort. Hier sou die bestudering van Afrikaans, 'n morfologies verarmde taal waarin Skuif overt plaasvind, 'n bydrae kon lewer tot die daarstelling van 'n teoretiese verklaring vir die eienskappe van STG. 


\section{NOTAS}

1 Sommige vroeë beskrywings van kinders met STG dateer uit 1822 (cf. Gall 1835). Verwys ook na Leonard (1998:5-8) vir 'n bondige oorsig oor die geskiedenis van die studie van STG.

2 'n Basiese kennis van sintaksis is 'n voorvereiste vir die verstaan van die inhoud van die meeste van hierdie verklarings. Raadpleeg Leonard (1998:213-221) of Van Dulm (2003) in hierdie verband.

3 Sommige van hierdie verklarings stel dit dat STG veroorsaak word deur beperkings in algemene kognitiewe prosesseringsvermoëns (cf. bv. Kail 1994) en ander dat die oorsaak van STG 'n agterstand in 'n baie spesifieke vermoë, soos fonologiese geheue, is. Sien Leonard (1998:269-273) vir 'n oorsig oor laasgenoemde tipe verklaring.

4 'n Asterisk word konvensioneel gebruik om aan te dui dat die gegewe linguistiese voorbeeldmateriaal ongrammatikaal is.

$5 \quad$ Sien die kort bespreking van binding in afdeling 3.1 .

6 Grammatikale morfeme is die geslote-klas morfeme van 'n taal. Ingeslote in hierdie klas is

(i) fleksiemorfeme (d.i., morfeme wat by 'n stam gevoeg word sonder om die stam se woordsoort te verander), wat in Engels die volgende vetgedruktes insluit: higher en highest (waar high, higher, en highest almal bywoorde of almal byvoeglike naamwoorde is); wandered en wandering (waar wander, wandered en wandering almal werkwoorde is); rooms (waar room en rooms beide naamwoorde is); thinks (waar think en thinks beide werkwoorde is); en written, soos in It has been written that ... (waar write en written beide werkwoorde is);

(ii) afleidingsmorfeme, wat in Afrikaans die volgende vetgedruktes insluit: eetbaar en bekoorlik (waar byvoeglike naamwoorde van werkwoorde afgelei is); amateuragtig en foutloos (waar byvoeglike naamwoorde van naamwoorde afgelei is); gesondheid (waar 'n naamwoord van 'n byvoeglike naamwoord afgelei is); speler, verskyning, en etery (waar naamwoorde van werkwoorde afgelei is); en rebelleer (waar 'n werkwoord van 'n naamwoord afgelei is); en

(iii) funksiewoorde, wat lidwoorde (soos die, daardie, en alle); hulpwerkwoorde; die infinitiewe merker to in Engels (soos in He tried to win); en die komplementeerders dat en of (soos in Hy sê dat dit waar is en Hy wonder of dit waar is) insluit (Radford 1997:38-56).

Voorsetsels behoort ook tot die geslote-klas morfeme, maar word nie as grammatikale morfeme beskou nie, aangesien voorsetsels, anders as grammatikale morfeme, duidelike en idiosinkratiese beskrywende inhoud het (Radford 1997:37). Teenoor geslote-klas morfeme staan oop-klas morfeme, wat naamwoorde, werkwoorde, bywoorde, en byvoeglike naamwoorde insluit. Hierdie klas morfeme word "oop" genoem omdat dit moontlik is om nuwe morfeme tot elk van hierdie kategorieë by te voeg, d.i., nuwe naamwoorde (soos Bush-isme of OBE), werkwoorde (soos netwerk of google), en bywoorde en byvoeglike naamwoorde (soos Oprah-agtig of you in That dress is very you) word tot tale toegevoeg. Hierteenoor word nuwe fleksie- en afleidingsmorfeme, nuwe funksiewoorde, of nuwe voorsetsels nie geskep nie. 
7 Hierdie bevindinge is ondersteun deur dié van Craig en Washington (2000).

8 Vir 'n bondige weergawe van die soeke na subgroepe kinders binne dié wat met STG gediagnoseer is en van die redes waarom STG bestudeer word, asook vir inligting oor die kriteria vir STG en oor die aard van STG, raadpleeg Leonard (1998:8-25).

9 "Tyd" word deurgaans met 'n hoofletter gespel om verwarring tussen grammatikale tyd (oftewel tempus of "tense") en die nie-tegniese sin van die woord te voorkom.

10 "Kongruensie" ("agreement") word gebruik om na die formele verhouding tussen twee woorde te verwys, waar 'n vorm van een woord 'n ooreenstemmende vorm van 'n ander woord vereis. Byvoorbeeld, as die subjek in die derdepersoon- enkelvoud vorm in Engels is, word daar vereis dat die finiete (d.i., Tydsgemarkeerde) werkwoord op die fleksiemorfeem -s eindig, soos in He plays the violin.

11 Sien Clahsen (1989) en Rice en Oetting (1993) vir ander verklarings wat tot hierdie groep behoort.

12 Sien Van Dulm (2003: afdeling 3.3) vir 'n bespreking van kenmerkkontrolering en Van Dulm (2003: afdeling 3.4) vir 'n bespreking van Skuif.

13 Sien Van Dulm (2003:27) vir 'n kort bespreking van die beginsel van Volle Interpretasie.

14 In minimalistiese sintaksis word daar voorgestel dat argumente met hul kasusmarkering uit die leksikon kom. Hiervolgens sal die argument dus nie skuif om kasus te ontvang nie (want die argument het reeds kasus), maar wel sodat sy kasus gekontroleer kan word (cf. Hornstein, Nunes, en Grohmann 2001:8-9; 2003:1, 22).

15 Sien Haegeman (1994:49-55) vir 'n inleidende bespreking oor die toekenning van tematiese rolle.

16 As 'n mens wel streng binne die raamwerk van minimalistiese sintaksis werk, sou daar wel 'n verklaring hiervoor wees. Sien die evaluering van Rice, Wexler en Cleave (1995) se Verlengde Opsionele Infinitief Hipotese (afdeling 3.2).

17 Sien Wexler (1994:312) vir 'n opsomming van wat die kind weet en doen in die Opsionele Infinitief stadium.

Sien Van Dulm (2003: afdeling 4.2) waar die Verdeelde INFL Hipotese bespreek word.

19 Dit is interessant om daarop te let dat kinders wat 'n tweedetaal aanleer soos STG-kinders optree in dié sin dat tekens van opsionele infinitiewe in beide groepe se uitinge aangetref word, soos bevind deur onder andere Håkansson (2001). Hierdie navorser het drie groepe Sweedssprekende kinders (normaal-ontwikkelende moedertaalsprekers, tweedetaalverwerwers en STG-kinders) op twee stadia met mekaar vergelyk. Daar is bevind dat die moedertaalsprekers in $85 \%$ van verpligte kontekste die werkwoord vir Tyd geïnflekteer het teenoor die $72 \%$ en $74 \%$ van onderskeidelik die tweedetaalsprekers en die STGkinders. Ses maande later was daar steeds verskille tuseen die groepe, alhoewel hierdie 
verskille nie meer statisties beduidend was nie (97\% vir die moedertaalsprekers van Sweeds, $88 \%$ vir die tweedetaalsprekers en $95 \%$ vir die sprekers met STG). Omdat beide STG-kinders en kinders wat in die proses van tweedetaalverwerwing is, ongeïnflekteerde werkwoordvorme gebruik, maan Paradis en Crago (2000:844-845) dat Tydsmarkering dus in eentalige kontekste 'n toepaslike kliniese merker van STG mag wees (cf. afdeling 5), maar nie noodwendig wanneer STG-kinders met hul tweetalige eweknieë vergelyk word nie.

Sien Van Dulm (2003: afdeling 3.1) vir 'n kort bespreking waarin daar na Uitspel verwys word.

21 Daar is ' $\mathrm{n}$ voorstel dat dít wat vantevore as koverte Skuif beskou is, in der waarheid overte Skuif mag wees, en wel overte Skuif van grammatikale kenmerke, d.i., dat kenmerke op hul eie skuif, sonder dat die leksikale item waarvan hulle deel vorm saam met hulle skuif (Hornstein, Nunes, en Grohmann 2003:par. 3.9.2.1). As hierdie voorstel aanvaar word, m.a.w. as daar nie 'n overt-kovert-onderskeid is nie, maar wel 'n onderskeid tussen die skuif van kenmerke en die skuif van kategorieë, dan is daar geen rede om aan te neem dat Skuif in sommige tale voor Uitspel en in sommige tale na Uitspel plaasvind nie. Dit is dan eerder die geval dat soveel Skuif-operasies as wat nodig is, uitgevoer word en dat Uitspel dan plaasvind (Hornstein et al. 2003:20).

22 Sien onder andere Leonard (1995); Leonard et al. (1992); Loeb en Leonard (1991); Rice et al. (1995); en Ullman en Gopnik (1994). Sien ook Van Dulm (2003: afdeling 3.2) vir 'n onderskeid tussen leksikale en funksionele kategorieë.

23 Let daarop dat ander navorsers (onder meer Leonard 1995) bevind het dat STG-kinders wel probleme toon met die besitlike 's in Engels.

24 Dit is nie duidelik waarom hierdie persone met STG nie probleme met refleksiewe voornaamwoorde getoon het nie, terwyl Van der Lely en Stollwerck (1997) bevind het dat STG-kinders wel sulke probleme toon. Dit kan wees dat die take en die visuele materiaal wat die twee navorsingspanne gebruik het om kennis van bindingsverhoudinge te evalueer op só 'n manier van mekaar verskil het dat dit die response beïnvloed het.

Hier is dit interessant dat die konstruksie wat Gopnik (1990b:715) as voorbeeld gee om die negatiewe passiewe konstruksie te illustreer wel omkeerbaar is, en dus die tipe passiewe konstruksie is waarmee STG-kinders volgens Van der Lely en Stollwerck (1997) probleme toon. Weer eens kan die twee verskillende response taakverwant wees: Aangesien Gopnik ten doel gehad het om die negatiewe passiewe konstruksie te toets, is dit moontlik dat die visuele toetsmateriaal, gekoppel met regte-wêreldkennis (wat in hierdie geval maak dat 'n situasie waarin 'n vragmotor ' $n$ kar trek meer waarskynlik is as en waarin 'n kar 'n vragmotor trek), veroorsaak het dat die omkeerbaarheid van die passiewe konstruksie nie die begrip daarvan beïnvloed het nie.

"Morfologiese paradigma" verwys hier na die stel vorme wat almal van dieselfde enkele stam afgelei is. Die vorme van die Engelse werkwoord jump, d.i., jump, jumps, jumping, en jumped, vorm byvoorbeeld 'n paradigma (Lyons 1981:202). Die paradigma van die teenwoordige tyd-vorm van dieselfde werkwoord in Duits sal as volg lyk: 


\begin{tabular}{llll} 
& & \multicolumn{2}{c}{ GETAL } \\
& & enkelvoud & meervoud \\
PERSOON & eerste & springe & springen \\
tweede & springst & springt \\
derde & springt & springen
\end{tabular}

27 Gopnik het dit teen die Oppervlak Hipotese, maar dieselfde kritiek kan teen die Morfologiese Rykheid Hipotese gerig word, en daarom word die twee hipoteses saam in hierdie afdeling geëvalueer.

28 Sien Clahsen (1991); Clahsen, Bartke, en Goellner (1997); Clahsen en Rothweiler (1992); en Linder en Johnston (1992) vir Duits; Jakubowicz (2003); Jakubowicz, Nash, Rigaut, en Gérard (1998); Paradis en Crago (2001); en Rose en Royle (1999) vir Frans; Dalalakis (1999) en Stavrakaki (2000, 2001a, 2001b, 2002) vir Grieks; Owen, Dromi, en Leonard (2001) en Rom en Leonard (1990) vir Hebreeus; Bortolini, Caselly, Deevy, en Leonard (2002); Bortolini, Leonard, en Caselli (1998); en Leonard, Sabbadini, Volterra, en Leonard (1988) vir Italiaans; Tanaka-Welty, Wanabe, en Menn (2002) en Fukuda en Fukuda (1994, 1999, 2001) vir Japannees; De Jong (2003) vir Nederlands; Håkansson (2001), waarna in eindnota 21 verwys word, Hansson en Leonard (2003), en Leonard, Salameh, en Hansson (2001) vir Sweeds; Ljubešić en Kovačević (1992) vir Kroasies; Vinkler en Pléh (1995) vir Hongaars; Crago en Allen (1994) vir Inuktitut; en Merino (1983) vir Spaans.

In Afrikaans word kongruensie nie foneties gerealiseer nie, nie in terme van getal-, persoon-, of geslagkenmerke nie. Kasus word foneties gerealiseer, maar net op persoonlike en besitlike voornaamwoorde. In terme van Tyd word [-Verledetyd] nie foneties gerealiseer nie, maar [+Verledetyd] wel, en op meer as een manier. In sinne sonder modale hulpwerkwoorde word daar van die aspektuele het en die verlede deelwoord gebruik gemaak om [+Verledetyd] aan te dui (soos in Ek het geswem), terwyl [+Verledetyd] in sinne wat modale hulpwerkwoorde bevat óf op dié hulpwerkwoorde aangedui kan word (soos in Ek kon swem) óf met die aspektuele het, waar die modale hulpwerkwoord dan in die teenwoordige of verledetydsvorm kan verskyn (soos in Ek kan/kon geswem het).

Sien byvoorbeeld Wiig en Semel (1984) vir 'n basiese inleiding tot hierdie onderwerp. Sien ook Aram en Nation (1980). 


\section{VERWYSINGS}

American Psychiatric Association. 1994. Diagnostic and statistical manual of mental disorders IV. Washington: American Psychiatric Association.

Aram, D.M. 1991. Comments on specific language impairment as a clinical category. Language, Speech, and Hearing Services in Schools 22: 84-87.

Aram, D.M. and J.E. Nation. 1980. Preschool language disorders and subsequent language and academic difficulties. Journal of Communication Disorders 13: 159-170.

Bishop, D.V.M., J. Chan, C. Adams, J. Hatley, and F. Weir. 2000. Conversational responsiveness in specific language impairment: Evidence of disproportionate pragmatic difficulties in a subset of children. Development and Psychopathology 12: 177-199.

Bortolini, U., M.C. Caselly, P. Deevy, and L.B. Leonard. 2002. Specific language impairment in Italian: The first steps in search for a clinical marker. International Journal of Language and Communication Disorders 37(2): 77-94.

Bortolini, U., L.B. Leonard, and M.C. Caselli. 1998. Specific language impairment in Italian and English: Evaluating alternative accounts of grammatical deficits. Language and Cognitive Processes 13(1): 1-20.

Chomsky, N. 1995. The minimalist program. Cambridge, USA: MIT Press.

Clahsen, H. 1989. The grammatical characterization of developmental dysphasia. Linguistics 27: 897-920.

Clahsen, H. 1991. Child language and developmental dysphasia. Linguistic studies of the acquisition of German. Amsterdam: Benjamins.

Clahsen, H., S. Bartke and S. Goellner. 1997. Formal features in impaired grammars: A comparison of English and German SLI children. Journal of Neurolinguistics 10: 151171.

Clahsen, H. and M. Rothweiler. 1992. Inflectional rules in children's grammars: Evidence from German particles. In G. Booij and J. van Marle (eds.) Yearbook of morphology 1992. Dordrect: Kluwer. pp. 1-34.

Conti-Ramsden, G. and A. Hesketh. 2003. Risk markers for SLI: A study of young languagelearning children. Journal of Language and Communication Disorders 38(3): 251263. 
Crago, M.B. and S.E.M. Allen. 1994. Morphemes gone askew: Linguistic impairment in Inukitut. McGill Working Papers in Linguistics 10(1/2): 206-215.

Craig, H.K. and J.A. Washington. 2000. An assessment battery for identifying language impairments in African American children. Journal of Speech, Language, and Hearing Research 43: 366-379.

Dalalakis, J. 1999. Morphological representation in specific language impairment: Evidence from Greek word formation. Folia Phoniatrica et Logopaedica 51: 20-35.

De Jong, J. 2003. Specific language impairment and linguistic explanation. In Y. Levy and J. Schaeffer (eds.) Language competence across populations. Toward a definition of specific language impairment. Mahwah: Lawrence Erlbaum Associates. pp. 151-170.

De Villiers, P.A., J.G. De Villiers, T. Roeper, H.N. Seymour, and B. Zurer Pearson. 2003. Unbiased assessment of first language acquisition in English: Distinguishing development and dialect from disorder. Stellenbosch Papers in Linguisitics Plus 32: 99-121.

Freedman, P. and R. Carpenter. 1976. Semantic relations used by normal and languageimpaired children at Stage I. Journal of Speech and Hearing Research 19: 784-795.

Fukuda, S. and S.E. Fukuda. 2001. The acquisition of complex predicates in Japanese specifically language-impaired and normally developing children. Brain and Language 77: 305-320.

Fukuda, S.E. and S. Fukuda. 1999. The operation of rendaku in the Japanese specifically language-impaired: A preliminary investigation. Folia Phoniatrica et Logopaedica 51: $36-54$.

Fukuda, S.E. and S. Fukuda. 1994. Developmental language impairment in Japanese: A linguistic investigation. McGill Working Papers in Linguistics 10(1/2): 150-177.

Gall, F. 1835. The function of the brain and each of its parts. 5, Organology. Boston: Marsh, Capen, and Lyon.

Goad, H. and C. Rebellati. 1994. Pluralization in specific language impairment: Affixation or compounding. McGill Working Papers in Linguistics 10(1/2): 24-40.

Gopnik, M. 1990a. Feature blindness: A case study. Language Acquisition 1(2): 139-164.

Gopnik, M. 1990b. Feature-blind grammar and dysphasia. Nature 344: 715.

Gopnik, M. 1994a. Impairments of syntactic tense in a familial language disorder. McGill Working Papers in Linguistics 10(1/2): 67-80. 
Gopnik, M. 1994b. The family. McGill Working Papers in Linguistics 10(1/2): 1-4.

Gopnik, M. 1994c. The Perceptual Processing Hypothesis revisited. McGill Working Papers in Linguistics 10(1/2): 135-141.

Haegeman, L. 1994. Introduction to government and binding theory. Second edition. Cambridge, USA and Oxford: Blackwell.

Håkansson, G. 2001. Tense morphology and verb-second in Swedish L1 children, L2 children and children with SLI. Bilingualism: Language and Cognition 4(1): 85-99.

Hansson, K, and L.B. Leonard. 2003. The use and productivity of verb morphology in specific language impairment: An examination of Swedish. Linguistics 41: 351-379.

Hornstein, N., J. Nunes, and K.K. Grohmann. 2001. Understanding minimalism: An introduction to minimalist syntax. Chapter 2. Some architectural issues in a minimalist setting. Manuscript.

Hornstein, N., J. Nunes, and K.K. Grohmann. 2003. Understanding minimalism: An introduction to minimalist syntax. Chapter 9. Feature interpretability and feature checking. Manuscript.

Ingram, D. and L. Carr. 1994. When morphology ability exceeds syntactic ability: A case study. Poster presented at the Convention of the American Speech-Language-Hearing Association, New Orleans.

Jakubowicz, C. 2003. Computational complexity and the acquisition of functional categories by French-speaking children with SLI. Linguistics 41(2): 175-211.

Jakubowicz, C., L. Nash, C. Rigaut, and C-L. Gérard (1998). Determiners and clitic pronouns in French-speaking children with SLI. Language Acquisition 7: 113-160.

Kail, R. 1994. A method of studying the generalized slowing hypothesis in children with specific language impairment. Journal of Speech and Hearing Research 37: 418-421.

Leonard, L.B. 1982. Phonological deficits in children with developmental language impairment. Brain and Language 16: 73-86.

Leonard, L.B. 1989. Language learnability and specific language impairment. Applied Psycholinguistics 10: 179-202.

Leonard, L.B. 1995. Functional categories in the grammars of children with specific language impairment. Journal of Speech and Hearing Research 38: 1270-1283.

Leonard, L.B. 1998. Children with specific language impairment. Cambridge, USA and London: MIT Press. 
Leonard, L.B., J. Bolders, and J. Miller. 1976. An examination of the semantic relations reflected in the language usage of normal and language handicapped children. Journal of Speech and Hearing Research 19: 371-392.

Leonard, L.B., U. Bortolini, M.C. Caselli, K.K. McGregor, and L. Sabbadini. 1992. Morphological deficits in children with specific language impairment: The status of features in the underlying grammar. Language Acquisition 2(2):151-179.

Leonard, L.B., L. Sabbadini, V. Volterra, and J.S. Leonard. 1988. Some influences on the grammar of English- and Italian-speaking children with specific language impairment. Applied Psycholinguistics 9(1): 39-57.

Leonard, L.B., E-K. Salameh, and K. Hansson. 2001. Noun phrase morphology in Swedishspeaking children with SLI. Applied Psycholinguistics 22(4): 619-640.

Loeb, D.F. and L.B. Leonard. 1991. Subject case marking and verb morphology in normally developing and specifically language-impaired children. Journal of Speech and Hearing Research 34: 340-346.

Linder, K. and J. Johnston. 1992. Grammatical morphology in language-impaired children acquiring English or German as their first language: A functional perspective. Applied Psycholinguistics 13: 115-129.

Ljubešić, M. and M. Kovačević. 1992. Some insights into specific language impairment in Croatian. Scandinavian Journal of Logopedics and Phoniatrics 17: 37-43.

Lyons, J. 1981. Language and linguistics. An introduction. Cambridge, UK: CUP.

Merino, B. 1983. Language development in normal and language handicapped Spanishspeaking children. Hispanic Journal of Behavioral Sciences 5: 379-400.

Morehead, D. and D. Ingram. 1973. The development of base syntax in normal and linguistically deviant children. Journal of Speech and Hearing Research 16: 330-352.

Oetting, J.B., M. Rice, and L. Swank. 1995. Quick incidental learning (QUIL) of words by school-age children with and without SLI. Journal of Speech and Hearing Research 38: 434-445.

O'Grady, W. 1997. Semantics: The analysis of meaning. In W. O'Grady, M. Dobrovolsky, and F. Katamba (eds.) Contemporary linguistics: an introduction. London and New York: Longman. pp. 269-312. 
Owen, A.J., E. Dromi, and L.B. Leonard. 2001. The phonology-morphology interface in the speech of Hebrew-speaking children with specific language impairment. Journal of Communication Disorders 34(4): 323-338.

Paradis, J. and M. Crago. 2000. Tense and temporality: A comarison between children learning a second language and children with SLI. Journal of Speech, Language, and Hearing Research 43: 834-837.

Paradis, J. and M. Crago. 2001. The morphosyntax of specific language impairment in French: An extended optional default account. Language Acquisition 9(4): 269-300.

Paradis, M. and M. Gopnik. 1994. Compensatory strategies in familial language impairment. McGill Working Papers in Linguistics 10(1/2): 142-149.

Pollock, J-Y. 1989. Verb movement, UG and the structure of IP. Linguistic Inquiry 20(3): $365-425$.

Radford, A. 1988. Small children's small clauses. Transactions of the Philological Society 86: $1-43$.

Radford, A. 1997. Syntax. A minimalist approach. Cambridge, USA: CUP.

Ravid, D., R. Levie, and G.A. Ben-Zvi. 2003. The role of language typology in linguistic development: Implications for the study of language disorders. In Y. Levy and J. Schaeffer (eds.) Language competence across populations. Toward a definition of specific language impairment. Mahwah: Lawrence Erlbaum Associates. pp. 171-193.

Rice, M., J. Buhr, and M. Nemeth. 1990. Fast mapping word-learning abilities of languagedelayed preschoolers. Journal of Speech and Hearing Disorders 55: 33-42.

Rice, M. J. Buhr, and J. Oetting. 1992. Specific-language-impaired children's quick incidental learning of words: The effect of a pause. Journal of Speech and Hearing Research 35: 1040-1048.

Rice, M. and J. Oetting. 1993. Morphological deficits in children with SLI: Evaluation of number marking and agreement. Journal of Speech and Hearing Research 36: 12491257.

Rice, M., J. Oetting, J. Marquis, J. Bode, and S. Pae. 1994. Frequency of input effects on word comprehension of children with specific language impairment. Journal of Speech and Hearing Research 37: 106-122. 
Rice, M. and K. Wexler. 1996. Towards tense as a clinical marker of specific language impairment in English-speaking children. Journal of Speech and Hearing Research 39: $1239-1257$.

Rice, M., K. Wexler, and P. Cleave. 1995. Specific language impairment as a period of extended optional infinitive. Journal of Speech and Hearing Research 38: 850-863.

Rom, A. and L.B. Leonard. 1990. Interpreting deficits in grammatical morphology in specifically language-impaired children: Preliminary evidence from Hebrew. Clinical Linguistics and Phonetics 4(2): 93-105.

Rose, Y. and P. Royle. 1999. Uninflected structure in familial language impairment: Evidence from French. Folia Phoniatrica et Logopaedica 51: 70-90.

Stavrakaki, S. 2000. Verb lexicons in SLI: Some experimental data from Modern Greek. Journal of Greek Linguistics 1: 93-129.

Stavrakaki, S. 2001a. "Asyntactic" comprehension: Evidence from SLI in Greek. Studies in Greek Linguistics 21: 724-735.

Stavrakaki, S. 2001b. Comprehension of reversible relative clauses in specifically language impaired and normally developing Greek children. Brain and Language 77: 419-431.

Stavrakaki, S. 2002. A-bar movement constructions in Greek children with SLI: Evidence for deficits in the syntactic component of language. In E. Fava (ed.) Clinical Linguistics. Theory and applications in speech pathology and therapy. Amsterdam and Philadelphia: John Benjamins. pp. 131-153.

Tanaka-Welty, Y., J. Wanabe, and L. Menn. 2002. Language production in Japanese preschoolers with SLI: Testing theories. In E. Fava (ed.) Clinical Linguistics. Theory and applications in speech pathology and therapy. Amsterdam and Philadelphia: John Benjamins. pp.175-193.

Tomblin, J., N. Records, P. Buckwalter, X. Zhang, E. Smith, and M. O'Brien. 1997. Prevalence of specific language impairment in kindergarten children. Journal of Speech, Language, and Hearing Research 40: 1245-1260.

Tower, D. 1979. Foreword. In C. Ludlow and M. Doran-Quine (eds.) The neurological bases of language disorders in children: Methods and directions for research. Bethesda: National Institutes of Health. pp. vii-viii.

Ullmann, M. and M. Gopnik. 1994. The production of inflectional morphology in hereditary specific language impairment. McGill Working Papers in Linguistics 10(1/2): 81-118. 
Van der Lely, H.K.J. 1994. Canonical linking rules: Forward versus reverse linking in normally developing and specifically language-impaired children. Cognition 51: 2972.

Van der Lely, H.K.J. 1996. Specifically language impaired children and normally developing children: Verbal passive vs. adjectival passive sentence interpretation. Lingua 98: 243272.

Van der Lely, H.K.J. 1998. SLI in children: Movement, economy and deficits in the computational-syntactic system. Language Acquisition 7: 161-192.

Van der Lely, H.K.J. 2003. Do hetereogeneous deficits require heterogeneous theories? SLI subgroups and the RDDR hypothesis. In Y. Levy and J. Schaeffer (eds.) Language competence across populations. Toward a definition of specific language impairment. Mahwah: Lawrence Erlbaum Associates. pp. 111-133.

Van der Lely, H.K.J. In press. Evidence for and implications of a domain-specific grammatical deficit. In L. Jenkins (ed.) The genetics of language. Oxford: Elsevier.

Van der Lely, H.K.J. and L. Stollwerck. 1997. Binding theory and grammatical specific language impairment in children. Cognition 62: 245-290.

Van Dulm, O. 2003. Syntax for speech-language pathologists. Stellenbosch Papers in Linguisitics Plus 32: 21-59.

Vinkler, Z. and C. Pléh. 1995. A case of a specific language impaired child in Hungarian. In M. Kovačević (ed.) Language and language communication barriers: Research and theoretical perspectives in three European languages. Zagreb: Croatian University Press. pp. 131-158.

Watkins, R., M. Rice, and C. Molz. 1993. Verb use by language-impaired and normally developing children. First Language 37: 133-143.

Wexler, K. 1994. Finiteness and head movement in early child grammars. In D. Lightfoot and N. Hornstein (eds.) Verb movement. New York: CUP. pp. 305-350.

Wexler, K. 2003. Lenneberg's dream: Learning, normal language development, and specific language impairment. In Y. Levy and J. Schaeffer (eds.) Language competence across populations. Toward a definition of specific language impairment. Mahwah: Lawrence Erlbaum Associates. pp. 11-61.

Wiig, E.H. and E. Semel. 1984. Language assessment and intervention for the learning disabled. Second edition. Columbus: Charles E. Merrill. 